J. Dairy Sci. 96:726-726

http://dx.doi.org/10.3168/jds.2013-96-1-726

(C) American Dairy Science Association ${ }^{\circledR}, 2013$.

\title{
Erratum to "Factors determining milk quality and implications for production structure under somatic cell count standard modification" (J. Dairy Sci. 95:6421-6435)
}

F. Dong, D. A. Hennessy, and H. H. Jensen

The following text appeared in the Introduction on page 6421:

"However, some states have recently lowered their state limits and many dairy processors have already imposed stricter standards on their producers (Norman et al., 2011). For example, California changed its upper limit to 600,000 cells/mL in 2009."

The authors inadvertently misread recent changes in California's milk regulations and the latter sentence should have read "For example, California has main- tained an upper limit on the SCC for Grade A milk of 600,000 cells/mL since 1990."

The authors regret the error.

\section{REFERENCES}

Dong, F., D. A. Hennessy, and H. H. Jensen. 2012. Factors determining milk quality and implications for production structure under somatic cell count standard modification. J. Dairy Sci. 95(11):6421-6435. 